\title{
PARA UN RETRATO DE YOLANDA BEDREGAL
}

\author{
POR \\ MARJORIE AGOSIN \\ Wellestey College
}

Este breve retrato de Yolanda Bedregal sólo pretende divulgar un exiguo bosquejo de su personalidad poética, así como parte de la temática encontrada en sus libros. Aún queda mucho por hacer con respecto a la lírica boliviana, en especial la de Yolanda Bedregal, quien, a pesar de su posición como una de las figuras poéticas más destacadas del país, no ha. sido objeto de estudios críticos a que es acreedora.

Por esos azares del destino llegué a conocer a Yolanda Bedregal en junio de 1985. Desde el primer momento impacta la vitalidad de esta delgadísima y diminuta mujer, que continúa desempeñando una actividad artística en áreas diversas, entre ellas la escultura y la pintura. Yolanda me obsequió, al encontrarnos, unas flores silvestres que crecen en el altiplano y me hacen sentir más cerca de ella y de su país. Emprendemos entonces. una caminata por las empinadas callejuelas de la ciudad de La Paz, hasta llegar a Goitia, 17.

La casa de Yolanda Bedregal es tan fascinante como su persona. Ubicada en la parte antigua de la ciudad de La Paz, parece ser una construcción. inmune al paso del tiempo, y también al olvido. Yolanda nos hace pasar y subimos por unas frondosas escaleras de caoba hasta llegar a su estudio, donde guarda tesoros, cartas de personajes literarios, entre ellas una bellísima dirigida a su esposo, Gert Conitzer, de Hermann Hesse, y pinturas de varios artistas latinoamericanos; las que más me sorprenden son las de su. hijo, Juan Conitzer, joven y gran pintor, con la extraordinaria capacidad de pintar como un niño. Son obras de fuerte colorido y escenas de la infancia, mezcladas con un trasfondo trágico y, a veces, alucinante.

Yolanda parece flotar, por estos cuartos, de los hallazgos donde la luz atraviesa los ventanales en irradiación límpida y magnética. Nos enseña, con naturalidad, sus esculturas, algunas de sus pequeñas nietas de siete y 
diez años, que también han penetrado la magia de los baúles de su abuela. Así pasamos toda una inolvidable tarde hablando de literatura y de comidas bolivianas, de familiares queridos y de plantas medicinales. Porque Yolanda no es un ser fragmentario, aislado de los quehaceres cotidianos e inmerso en su arte, sino que ella es parte de todas las cosas que la rodean, y, con igual naturalidad, cuenta del día en que la nombraron Yolanda de Bolivia o del hecho de que hace muchos años que nadie se preocupa del jardín de la casa.

Es difícil hablar de Bolivia sin mencionar a Yolanda y a su familia de intelectuales y artistas, especialmente a su padre, fallecido, Juan Francisco Bedregal, catedrático y rector de la Universidad de La Paz por muchos años. Yolanda nació en dicha ciudad el 21 de septiembre de 1918, en la misma casa en que me recibe. Estudió Bellas Artes en la Universidad de San Andrés, y posteriormente se desempeña como profesora en dicha institución. También estudió en Barnard College, en los años cuarenta. Su primer libro de poemas, Naufragio, fue publicado en 1936, y desde esa época su actividad literaria no cesa. En 1948 es nombrada Yolanda de Bolivia por el Gobierno de su país y en el año 1982 recibe del Gobierno argentino y de la Sociedad de Escritores de la Argentina el título de Yolanda de América. Laureada con muchos premios, entre ellos el Premio Nacional de Poesía y el Premio de Novela Guttentag, también de Bolivia, por su única novela, Bajo el oscuro sol (1971), Yolanda Bedregal es una de las figuras más destacadas de la literatura boliviana y de la América hispánica. Sin embargo, repetimos, su obra no ha sido estudiada con la atención y el detenimiento que se merece.

Para entender a Yolanda Bedregal no basta aceptar su tan generosa invitación a deambular por su casa, o su tierna sonrisa, con ojos que lo entienden todo. Yolanda Bedregal es su poesía, que viene desarrollándose y consolidándose a través de los años. Ya en Naufragio se percibe esa fina sutileza para decir las cosas, como también las deslumbrantes imágenes que no la abandonarán a través de toda su obra. El primer poema de este libro, «Invitación al viaje», ejemplifica el tono de la colección: «Rememoraciones de la infancia. Recuerdo de algunas escenas.» Es un libro poético cuyo tema central radica en la nostalgia del pasado y en la apreciación del mundo del niño. En el año 1978 Bedregal publicó El cántaro del angelito, poemas dedicados a los infantes, con una exquisita sensibilidad que hace que tanto adultos como niños participen en estas evocaciones de ensueño. En «Invitación al viaje», la autora nos dice: «Voy a darte migas de pan y piedras blancas de Pulgarcito para que sigas los caminos» (p. 11). Naufragio muestra el seguro talento poético de Yolanda, expresado en una prosa poética cuidadosamente labrada, en la cual la descripción pictórica 
de los estados de ánimo es la nota central: «Hace tiempo, la luna en creciente me parecía una barca y nos encargábamos de llenarla de una neblina amorosa, donde una niña muerta se cubría de jazmines» (p. 52).

En su segundo libro, Poemar (1937), continúa con algunos de los temas de Naufragio, que enriquece con una preocupación por su ciudad, los alrededores y la cultura indígena que la rodea; tal el poema «Mis paisajes»: «Lejanía, lejanía / Pampa / Cielo / Bajo bravo viento / y un punto ardiente / como un grito / tu poncho colorado, hermano indio» (p. 43). Es interesante ver que esta misma obsesión por su tierra, por su gente, se refleja en uno de sus libros más logrados: Nadir (1950), especialmente en el tierno poema dedicado a la nodriza que la cuida: "Mamacha morena de la raza aymara / en cuyas rodillas dormimos de niños / hoy que estás viejita / quieren nuestros brazos también cobijarte» («Para la buena Mama Peta», p. 46). Aparece más tarde en su última colección de poemas, Ayllu (1984), hecha en colaboración con Peter McFarren, fotógrafo y corresponsal de la Associated Press en Bolivia. Los textos de Bedregal matizan y se unen a las espectaculares fotografías de McFarren, que cubren desde los desolados altiplanos hasta los festivales de danza de Oruro. Bedregal, con exquisita capacidad de síntesis, elabora las imágenes con la precisión de una fotógrafa de la palabra: «El viento henchido y los pies descalzos / vienen y van a la fuente» (Ayllu, sin página).

Con Ecos, Bedregal inicia una nueva fase lírica basada en la tradición mística hispánica; además, la segunda parte del libro contiene una traducción de Bedregal, del alemán al castellano, de los poemas de su esposo Gert Conitzer. En este libro aparece nuevamente esa «sed» por captar lo que la rodea: «No quiero / agua / ni sangre / ni vino para mi sed / Tengo sed de Eternidad / en la copa de vidrio / de un instante fugaz» («Sed», p. 33).

En Nadir (1952) culmina el proceso místico que definirá la obra madura de Bedregal. Muchos poemas tienen un motif religioso especial, en los cuales se le pide al Todopoderoso entendimiento del universo que la circunda: "Señor, cuando sea otoño y la flor no esté firme / quiero que me acompañes a ver el desnudarse de mi mundo» («Nocturno en Dios», p. 61).

Almadia (1956) y Del mar y la ceniza (1957) son dos poemarios maduros que ejemplifican una construcción más prosaica de las estrofas y una observación filosófica de su acontecer. Atrás han quedado las evocaciones líricas de la infancia, y se observa ahora un regreso a la realidad concreta: «Un auto ha arrollado a la vieja sirviente. / La pisó como a una hoja. / Era una flor de campo / ... toronjil, yerbabuena. / En la casa hubo due10 / por su muerte de plata» (Almadia, «Alegría humilde», p. 55). Esa 
misma sirvienta es la nodriza de antaño, observada bajo el trasluz de la artista consciente de su arte, integrada al ambiente que la rodea. Pero también su obra se despliega en abstracciones metafóricas que expresan la realidad interior de sí misma, maravillosamente lograda en uno de los libros más distintivos de la autora: el poemario Del mar y la ceniza. A mi parecer, la obra de Yolanda Bedregal tiene, desde sus comienzos, una coherencia orgánica, que empieza con la búsqueda y la exaltación de la niñez y se asume finalmente en la búsqueda místico-religiosa de su ser. Sin embargo, Del mar y la ceniza es un libro que se sale de esta trayectoria, al presentar, con fluidez, imágenes plásticas y coloridas, prodigadas en un paisaje marino, y que se identifican con un estado casi sonámbulo y ebrio que también busca ceñirse a un centro de espiritualidad: «Una mansa locura de amor el ser invade / la ceniza inicial de la sangre se evade / a la porción recóndita de sal sobre la marea / que en vigilante insomnio cada orilla golpea» (p. 7).

Sin lugar a dudas, Yolanda Bedregal es un nombre y una presencia de relevante valor en la lírica boliviana, y en especial, en la de las mujeres latinoamericanas. Con sus poemarios, sus innumerables crónicas de viajes, reseñas, su poesía de niños, su obra es de una indiscutible riqueza, al igual que esa generosa persona que permitió el acceso a su casa, a los lugares íntimos, a las cosas amadas que formaron y forman parte de sus versos. Porque conocer a Yolanda Bedregal es adentrarse en Bolivia, con todas sus pasiones y sus tristezas. Nos despedimos, y ella me obsequia un equeco de plata para que la buena suerte me sonría; y ella me sonríe, y esa sonrisa es parte indisoluble de Yolanda Bedregal. 